\title{
Current agro-climatic potential of Patagonia shaped by thermal and hydric patterns
}

\section{Andrea Soledad Brendel, Ricardo Alfredo del Barrio, Francisco Mora, Elmer Adolfo Orrego León, Johaner Rosales Flores, et al.}

Theoretical and Applied Climatology

ISSN 0177-798X

Volume 142

Combined 3-4

Theor Appl Climatol (2020) 142:855-868

DOI 10.1007/s00704-020-03350-w 
Your article is protected by copyright and all rights are held exclusively by Springer-Verlag GmbH Austria, part of Springer Nature. This eoffprint is for personal use only and shall not be self-archived in electronic repositories. If you wish to self-archive your article, please use the accepted manuscript version for posting on your own website. You may further deposit the accepted manuscript version in any repository, provided it is only made publicly available 12 months after official publication or later and provided acknowledgement is given to the original source of publication and a link is inserted to the published article on Springer's website. The link must be accompanied by the following text: "The final publication is available at link.springer.com". 


\title{
Current agro-climatic potential of Patagonia shaped by thermal and hydric patterns
}

\author{
Andrea Soledad Brendel ${ }^{1,2}$ (D) Ricardo Alfredo del Barrio ${ }^{2,3} \cdot$ Francisco Mora $^{2}$ • Elmer Adolfo Orrego León ${ }^{4}$. \\ Johaner Rosales Flores ${ }^{5}$. José Antonio Campoy ${ }^{6}$
}

Received: 28 January 2019 / Accepted: 7 August 2020 / Published online: 16 August 2020

(C) Springer-Verlag GmbH Austria, part of Springer Nature 2020

\begin{abstract}
Changes in thermal and hydric patterns affect crop growth. This research is aimed to assess temporal and spatial trends of 18 climatic and agro-climatic thermal and hydric indices in the north of Argentine Patagonia ( $39^{\circ}-44^{\circ}$, south latitude), to establish the current and potential suitability of this region for agriculture in a context of climate change. The period of study was 19702016, and it was focused on the last 20 years. Regional warming was indicated by the average increases of annual mean temperature $\left(+0.2^{\circ} \mathrm{C}\right.$ decade $\left.^{-1}\right)$, mean maximum temperature of the warm trimester $\left(+0.3^{\circ} \mathrm{C} \mathrm{decade}^{-1}\right)$, and extreme maximum temperature of the warmest month $\left(+0.6^{\circ} \mathrm{C} \mathrm{decade}^{-1}\right)$ during 1970-2016. This trend was also found in the 1996-2017 period. Mean minimum temperature of the cold trimester showed an uneven spatial and temporal trend, with increasing temperatures during 1970-2016 $\left(+0.1^{\circ} \mathrm{C}\right.$ decade $\left.^{-1}\right)$, but a negative trend $\left(-0.1{ }^{\circ} \mathrm{C}\right.$ decade $\left.{ }^{-1}\right)$ over the last 20 years, which leads to an increasing regional trend in temperature amplitude. Negative trends in extreme minimum temperatures of April $\left(-0.3{ }^{\circ} \mathrm{C}\right.$ decade $\left.^{-1}\right)$, July and October $\left(-0.2{ }^{\circ} \mathrm{C} \mathrm{decade}^{-1}\right)$ imply more significant risks of cold damage for crops that exhibit sensitive phenological stages during this time. Thermal agro-climatic indices showed negative trends in winter chill ( -15.8 chill hours decade $^{-1}$ considering the Weinberger method and -20.8 chill hours decade ${ }^{-1}$ using Sharpe method) and higher accumulation of warm semester growing degree days $\left(+38.8 \mathrm{GDD}_{5}{ }^{\circ} \mathrm{C}\right.$ and $+32.3 \mathrm{GDD}_{10}{ }^{\circ} \mathrm{C}$ decade $\left.{ }^{-1}\right)$. Climatic and agro-climatic water indices showed that most of the region experienced decreasing water availability, mainly in the central-south and Andean subregions, showing annual precipitation trends of -11.5 and $-31.2 \mathrm{~mm} \mathrm{decade}^{-1}$, respectively). If these thermal and hydric trends are maintained in the future, the region will evolve into an area of greater energetic availability but with some restrictions: lower winter chill that would affect very high-chill cultivars cultivated in the warmest regions, higher risk of extreme thermal events during crucial phenological periods of specific crops, and decreasing water availability that would mainly affect dryland farming and river basin recharge.
\end{abstract}

\section{Introduction}

In recent decades, many regions of the world have experienced changes in the temperature and precipitation at different temporal and spatial scales (Alexander et al. 2006; Brown et al. 2008; Westra et al. 2013). According to the Intergovernmental Panel on Climate Change (IPCC 2013), the global temperature increased by $0.85{ }^{\circ} \mathrm{C}$ between 1880

Andrea Soledad Brendel and Ricardo Alfredo del Barrio contributed equally to this work.

Andrea Soledad Brendel

andreabrendeluns@gmail.com; asbrendel@iado-conicet.gob.ar

Extended author information available on the last page of the article and 2012. Moreover, growing trends in the frequency of extreme weather events and their intensity have been observed during the last 50 years (IPCC 2013). Biological observations indicate that these changes are already affecting living systems (Parmesan and Yohe 2003).

In South America, extreme temperatures have changed over the period 1960-2000. Significant trends were observed in the indices based on minimum daily temperatures. Significant increasing trends in the percentage of warm nights and decreasing trends in the percentage of cold nights were observed at many stations (most of the Argentine and Chilean Patagonian stations) (Vincent et al. 2005). In most parts of non-Patagonian Argentina, the annual mean temperature increased by $0.5^{\circ} \mathrm{C}$ between 1960 and 2010, while the precipitation showed the same sign of trend in almost the whole country. This precipitation rise is higher than $100 \mathrm{~mm}$ in some 
semiarid areas, which has increased the land use for agriculture in these areas (Secretariat of Environment and Sustainable Development, SAyDS 2015). On the other hand, in the Argentine Pampas region, in the most crucial part of the country from an agricultural point of view, the maximum daily temperatures decreased, whereas the minimum daily temperatures increased during the period 1940-2007 (FernándezLong et al. 2013). Moreover, Doyle et al. (2012) determined significant positive trends in the annual precipitation in 47 stations located in the Río de La Plata river basin in the period 1960-2005.

In the Patagonian region, in the southernmost part of the country, the main rainfed agricultural activity is extensive domestic livestock, with natural pastures as the fodder source, so their condition and perspective are fundamental in terms of sustainability and development (Oñatibia and Aguiar 2016). North Patagonian intensive agriculture is located in valleys, and it represents the $85 \%$ and $75 \%$ of the country's total production of apples and pears, respectively (Argentine Board of Integrated Fruit Growers 2018). In this region, the most extreme climate changes are the rise of the average annual or seasonal temperature. Although these changes have been reported since 1970, they became highly relevant since 1990 (Rabassa 2010). Rusticucci and Barrucand (2004) determined that the increase in the number of warm days and nights in winter and the decrease in the number of cold days and nights in summer during the 1959-1998 period in north Patagonia were due to the thermal increase. According to SAyDS (2015), from 1960 to 2010, the annual mean temperature increments recorded in this region were higher than in the rest of the country, whereas the precipitation in the Patagonian Cordillera decreased which is reflected in the water level. However, precipitation has not presented a clear spatial pattern (Rabassa 2010).

Changes in thermal and hydric patterns, like those previously presented, considerably affect the growth and development of plants and ecosystems as a whole (Garcia et al. 2014), as well as the activities related to agriculture (e.g., the selection of crop locations, irrigation or fertilization) (Nasir et al. 2018). Precipitation decrease directly affects crop growth rates, whereas rising temperatures catalyze phenological behavior in both crops and the natural vegetation (Legave et al. 2013).

To date, there is little information on how climatic trends are likely to affect the suitability of the Argentine Patagonia for different types of agricultural production (Brendel et al. 2017; Garcia Martinez et al. 2017). Recently, del Barrio et al. (2020) evaluated the possible impacts of climate change, focusing on thermal patterns and projections on regional cultivation of deciduous fruit and nut trees. The present research aims to assess the temporal and spatial trends in climatic and agro-climatic thermal indices and water indices in the northern region of Argentine Patagonia during the last five decades to illustrate the current agricultural suitability in a context of climate change.

\section{Materials and methods}

\subsection{Study area}

Two significant gradients shape the Patagonian climatic heterogeneity: rainfall decreases from west to east, whereas temperature decreases from the northeast to the southwest (Alessandro 2008). The seasonal displacement of the semipermanent subtropical high-pressure in the Pacific Ocean and the coastal ocean currents with an Equatorial direction, as well as the presence of the Andes mountain range, determine the spatial rainfall patterns, of 800 to $1000 \mathrm{~mm} \mathrm{year}^{-1}$ in the western mountain or foothill area and up to $200 \mathrm{~mm}$ on the central plateau (Barrett et al. 2009). In coastal areas, the northdirection air masses from the Atlantic Ocean generate sporadic convective rainfall during summer and early autumn. Consequently, the annual average is minimum in the central Patagonian and increases to the northeast, with values about $400 \mathrm{~mm}$ per year (Bianchi et al. 2016).

Regarding the temperature, this regional climate ranges from temperate to cool temperate, cold summer in the west, and cold arid in the central steppe (Kottek et al. 2006). It is dominated by air masses coming from the Pacific Ocean and by the circulation of moderate to strong westerly winds. The isotherms have a northeast-southwest distribution due to the combined effect of latitude, altitude, and regional circulation. So, the annual mean temperature varies between 8 and $15^{\circ} \mathrm{C}$, with means of $14-22{ }^{\circ} \mathrm{C}$ in January and $2-8{ }^{\circ} \mathrm{C}$ in July (Alessandro 2012).

The study area is a sub-region of Argentine Patagonia, called North Patagonia, which includes the south of the Buenos Aires province and the provinces of Río Negro, Neuquén, and Chubut, between $39^{\circ}$ and $44^{\circ}$ SL (Fig. 1). It comprises $20 \%$ of the national territory, but it only has $4.3 \%$ of its inhabitants with an average population density of 3.2 inhabitants $\mathrm{km}^{-1}$. Due to the climate conditions, regional agriculture is currently dominated by extensive livestock farming: cattle in the north and west, and sheep and goats in the central and southern plateaus of the region. In the main river valleys, fruits, vegetables, and forages for fattening cattle production are reliant on irrigation. Most of the Argentine apple and pear production $(\sim 85 \%)$ is located along the Neuquén and Negro river valleys. In the Colorado river basin, we found the same scenario but to a lesser extent. On the other hand, towards the south, the lower Chubut River valley featured pastures, vegetables, and cherry production.

\subsection{Meteorological data}

To characterize the local climatic and agro-climatic conditions, monthly air temperature and rainfall data from $11 \mathrm{me}-$ teorological stations located in the study area (Table 1, Fig. 1) were analyzed. The meteorological data were obtained from 


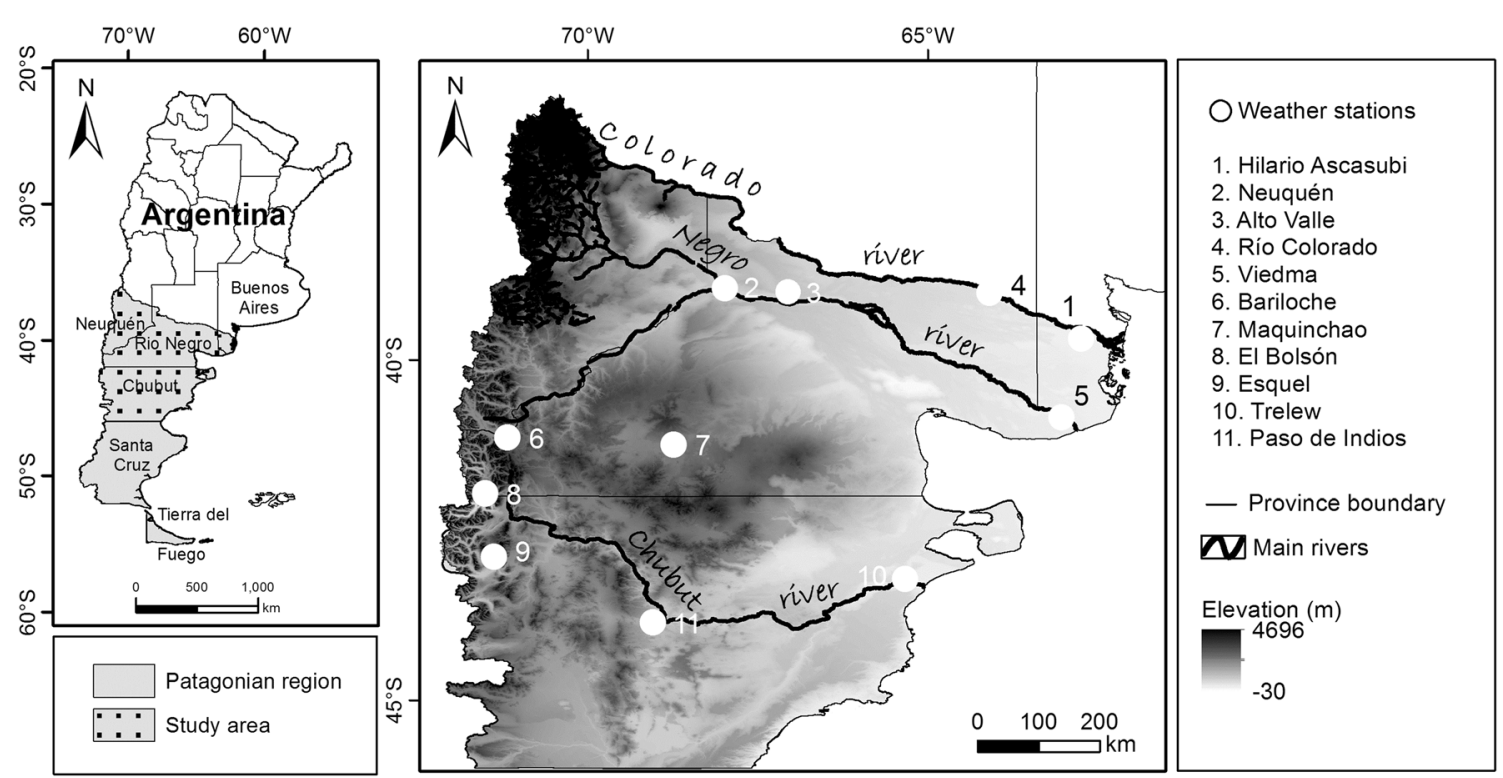

Fig. 1 Location map of North Patagonia (Argentina), the weather stations and elevation

the National Weather Service (SMN) and the National Institute of Agricultural Technology (INTA).

The scarcity of meteorological stations with extensive historical records is related to the low population, which is concentrated mainly along the rivers in a vast and otherwise climatically inhospitable territory. The period of study is 1970 2016. We conducted separate analyses for the period from 1997 to 2016 to detect possible changes in climatic trends, as indicated in previous studies (i.e., Rabassa 2010; Brendel et al. 2017). The partitioned analysis of a time series is typical in climatology and agro-climatology to establish possible differences between the complete records and the records of the recent past (Fernández-Long et al., 2013; Adnan et al. 2017; Chen et al. 2017). We implemented a data quality assessment by using the guide of the World Meteorological Organization (WMO 2011).

\subsection{Climatic and agro-climatic indices}

We calculated 18 climatic and agro-climatic indices to describe the local temperature and precipitation regimes (Table 2). Both types of indices to consider phenological times and bioclimatic requirements of the main deciduous fruit trees possible to be grown in the region. This strategy is widely supported by previous research using similar indices for different crops and regions (Moonen et al. 2002; Qian et al. 2013; Fernández-Long et al. 2013; Adnan et al. 2017). The choice of indices was supported by previous work on the suitability of the region for various crops, such as apple (Pascale et al. 2003), cherry (Cittadini et al. 2008), olive (Martín and Gallo 2007), walnut and hazelnut (del Barrio and Martín 2011), and grapes (del Barrio et al. 2016). Brendel et al. (2017) previously described some of these thermal indices (i.e., the absolute maximum temperature of the warmest month January) focusing on the agro-climatic feasibility for walnut production; however, in the current study we analyzed the trend of each index and we also developed a map containing the statistical significance of each index and the results obtained on the agro-climatic potential of Patagonia for the main deciduous temperate fruit tree production.

Besides computing the annual mean temperature (AMT), we also calculated aggregated temperature metrics for certain parts of the year. The mean maximum temperature during the warmest quarter of the year (December, January, and February) (MeMaxTDJF) allows an approximation of thermal energy available during the most active period of the local vegetation. In contrast, the mean minimum temperature during the coldest quarter of the year (June, July, and August) (MeMinTJJA) provides information on frost severity and chill availability, which are critical site parameters for most perennial crops from temperate climates. Following the previous indices, the annual thermal amplitude (ATA) is another relevant parameter for crop physiology. In the present study, this index was calculated from the difference between the mean maximum temperature in January, and the mean minimum temperature in July.

Extreme monthly and annual temperatures, both minimum and maximum, are indicative of the severity of extreme thermal events. Regarding intensity, recurrence, and trend, they are of great importance because of their impact on crop productivity. Accordingly, we also analyzed trends in the absolute (extreme) maximum temperature of the warmest monthJanuary-(aMAXTJa), which we considered a thermal stress approach that can impact crops in several ways, including changes in sugar concentration and variation in fruit color, 
Table 1 Locations of weather stations used in this study in the period 1970-2016

\begin{tabular}{llllllll}
\hline Weather station & Province & Lat. & Long. & Elev. $(\mathrm{m})$ & $\begin{array}{l}T_{\max } \text { January } \\
\left({ }^{\circ} \mathrm{C}\right) \text { and Sd }\end{array}$ & $T_{\min }$ July $\left({ }^{\circ} \mathrm{C}\right)$ and Sd & Pp. annual (mm) and Sd \\
\hline Hilario Ascasubi & Buenos Aires & -39.38 & -62.62 & 22 & $30.0 \pm 1.1$ & $1.6 \pm 1.5$ & $492 \pm 105.7$ \\
Neuquén & Neuquén & -38.57 & -68.08 & 271 & $31.7 \pm 1.2$ & $0.3 \pm 1.3$ & $194 \pm 82.2$ \\
Alto Valle & Río Negro & -39.03 & -67.74 & 242 & $30.5 \pm 1.8$ & $-0.7 \pm 1.3$ & $234 \pm 92.3$ \\
Rio Colorado & Río Negro & -39.01 & -64.05 & 59 & $31.7 \pm 1.2$ & $2.7 \pm 1.5$ & $464 \pm 125.5$ \\
Viedma & Río Negro & -40.85 & -63.02 & 7 & $29.3 \pm 1.3$ & $1.6 \pm 1.3$ & $377 \pm 114$ \\
Bariloche & Río Negro & -41.15 & -71.17 & 840 & $22.4 \pm 2.3$ & $-1.5 \pm 1.3$ & $809 \pm 180.5$ \\
Maquinchao & Río Negro & -41.25 & -68.73 & 887 & $26.3 \pm 1.6$ & $-4.0 \pm 1.9$ & $202 \pm 77.5$ \\
El Bolsón & Río Negro & -41.97 & -71.50 & 337 & $24.7 \pm 2.4$ & $-0.8 \pm 1.3$ & $866 \pm 171.8$ \\
Esquel & Chubut & -42.90 & -71.37 & 787 & $21.6 \pm 1.9$ & $-2.6 \pm 1.9$ & $493 \pm 109.3$ \\
Trelew & Chubut & -43.23 & -65.30 & 10 & $28.9 \pm 1.4$ & $0.6 \pm 1.3$ & $203 \pm 72.2$ \\
Paso de Indios & Chubut & -43.87 & -69.03 & 590 & $26.5 \pm 1.8$ & $-2.3 \pm 2.1$ & $172 \pm 75.6$ \\
\hline
\end{tabular}

Lat. latitude, Long. longitude, Elev. elevation, $T_{\max }$ mean maximum temperature in January, $T_{\min }$ mean minimum temperature in July, $P p$. Annual mean annual precipitation, $S d$ standard deviation

size, and quality. On the other hand, the absolute minimum temperature of the coldest month (July) (aMINTJl) indicates the intensity of winter frost, which can damage plant tissue even during the dormant season, if temperatures drop below plant-specific thresholds. Furthermore, the absolute minimum temperatures in April (aMINTAp) and October (aMINTO) were used to indicate the early/autumn and late/spring frost intensities, respectively, associated with the critical phenological stages of the crops in the region studied.

The selection of agro-climatic thermal indices was based on general criteria related to agricultural activities, mainly fruit growth, with pome fruit (apple and pear), nut fruit (walnut and hazelnut), stone fruit (peach and plum, and to a small extent cherries), grapes, and olive being cultivated in the region.
In deciduous fruit trees, the dormant season can be divided into two main stages (paradormancy-correlative inhibition - is not considered here). During the first phase, often termed endodormancy, the chilling requirement has not been fulfilled. After that, during the ecodormancy phase, the tree no longer accumulates chilling, and leaf out or bloom will occur after the respective forcing or heat requirements for these stages have been fulfilled (Luedeling et al. 2009a).

Trees require a winter chill to overcome their endodormancy period, and chill availability is an essential factor for the suitability of species and cultivars in a given area (Campoy et al. 2011). Various models have been proposed for estimating chill, with the so-called Dynamic Model currently the front-runner (Luedeling 2012). To ensure

Table 2 Analyzed climatic and agro-climatic indices

\begin{tabular}{|c|c|}
\hline Climatic & Agro-climatic \\
\hline \multicolumn{2}{|l|}{ Thermal } \\
\hline Annual mean temperature (AMT) & Thermal sums on base $10{ }^{\circ} \mathrm{C}$ October-March $\left(\Sigma \mathrm{T} 10{ }^{\circ} \mathrm{C}\right)$ \\
\hline $\begin{array}{l}\text { Mean maximum temperature } \\
\text { December-January-February quarter (MeMaxTDJF) }\end{array}$ & Thermal sums on base $5{ }^{\circ} \mathrm{C}$ October-March $\left(\Sigma \mathrm{T} 5{ }^{\circ} \mathrm{C}\right)$ \\
\hline $\begin{array}{l}\text { Mean minimum temperature June-July-August quarter } \\
\text { (MeMinTJJA) }\end{array}$ & Chilling hours Weinberger (CHW) \\
\hline Annual thermal amplitude (ATA) & Chilling hours Sharpe (CHS) \\
\hline \multicolumn{2}{|l|}{$\begin{array}{l}\text { Absolute maximum temperature January (aMAXTJa) } \\
\text { Absolute minimum temperature July (aMINTJl) }\end{array}$} \\
\hline \multicolumn{2}{|l|}{ Absolute minimum temperature April (aMINTAp) } \\
\hline \multicolumn{2}{|l|}{ Absolute minimum temperature October (aMINTO) } \\
\hline \multicolumn{2}{|l|}{ Water } \\
\hline Annual precipitation (AnnualPP) & Annual Precipitation minus Potential Evapotranspiration (Thornthwaite) (annual PP-PET) \\
\hline $\begin{array}{l}\text { Precipitation accumulated in the warm semester } \\
\text { (October-March, WarmPP) }\end{array}$ & $\begin{array}{l}\text { Precipitation minus Potential Evapotranspiration (Thornthwaite) accumulated in the warm } \\
\text { semester (October-March, Warm PP-PET) }\end{array}$ \\
\hline $\begin{array}{l}\text { Precipitation accumulated in the cold semester } \\
\text { (April-September, ColdPP) }\end{array}$ & $\begin{array}{l}\text { Precipitation minus Potential Evapotranspiration (Thornthwaite) accumulated in the cold } \\
\text { semester (April-September, Cold PP-PET) }\end{array}$ \\
\hline
\end{tabular}


comparability with earlier analyses, and because the Dynamic Model requires hourly data which cannot easily be generated from the monthly information used in this study, we opted for an alternative method for estimating chill that is based on established relationships between mean temperatures during the winter months and the number of Chilling Hours.

We used two alternative models for this estimation. The first model, (according to Weinberger 1950) CHW, derives chill from mean monthly temperatures in June ( $t \mathrm{Jn}$ ) and July $(t \mathrm{Jl})$ as defined in Eq. (1):

$\mathrm{CHW}=2124.95-125.23 *\left(\frac{t \mathrm{Jn}+t \mathrm{Jl}}{2}\right)$

A second procedure according to Sharpe (1970) is CHS, who established a correlation between chill hours and the monthly mean temperatures of May, June, July, August, and September. The CHS was calculated using the following equation (Eq. 2):

$\mathrm{CHS}=\sum \mathrm{CH}_{\text {month }}$

$\mathrm{CH}_{\text {month }}=638-33,007 * T_{\text {mean }}$

where $\mathrm{CH}$ month is the monthly chill hour estimate, and $T_{\text {mean }}$ is the monthly mean temperature of the respective month (May, June, July, August, and September). The total (CHS) is the sum of all monthly chill estimates.

While this method of estimating chill would not be acceptable in warm climates, where the Chilling Hours model has produced inferior results (Benmoussa et al. 2017), it should be effective under the cool temperate conditions of our study area (Luedeling and Brown 2011). Perennials also need heat in spring to leaf out and bloom, and for all subsequent development periods. Heat requirements are often quantified in Growing Degree Days (GDD) that express thermal sums. Since the base temperatures used as a lower threshold for heat accumulation vary between species, varieties, or cultivars, we conducted separate calculations for base temperatures of $5{ }^{\circ} \mathrm{C}$ and $10{ }^{\circ} \mathrm{C}$, which spans the values suggested in the literature for temperate-zone fruit trees with potential suitability in the region: walnut (Vahdati et al. 2012), olive (Galán et al. 2005; Pérez-López et al. 2008), and grapevine (Duchêne et al. 2010). According to equations reported by Pascale and Damario (2004), we estimated monthly heat availability as (Eq. 3):

$\sum T_{\mathrm{LN}}=0.5 \frac{(t M-t b)^{2}}{t M-t m}$

where $t M$ is the monthly mean maximum temperature, $t m$ is the monthly mean minimum temperature, and $t b$ is the base temperature $\left(5^{\circ} \mathrm{C}\right.$ and $\left.10^{\circ} \mathrm{C}\right)$ during October-March.

Precipitation represents the primary water source in Argentine Patagonia. The region is characterized by low average annual rainfall. The coastal zone and the central plateau and valleys show different annual precipitation regimes (Aravena and Luckman 2009). In the Andean region, precipitation falls predominantly during the cold semester (González and Vera 2010), whereas the coastal and central zones present a relatively homogeneous distribution throughout the year, with slightly higher precipitation during the warm semester (Bianchi et al. 2016). Therefore, we computed the annual accumulated precipitation (AnnualPP), the precipitation collected in the warm semester October-March (WarmPP), and the precipitation accumulated in the cold semester AprilSeptember (ColdPP) to characterize regional moisture regimes (Table 2).

To characterize the water use as well as the water supply, we added an analysis of the accumulated precipitation minus potential evapotranspiration (PP-PET) (Table 2). The use of PET allowed us to identify, analyze, and monitor the soil water balance and drought events more precisely (MartínezFernández et al. 2015). The PP-PET (mm) may be calculated at different scales. In this study, it was applied at an annual scale (annual PP-PET) and during the warm (warm PP-PET) and cold (cold PP-PET) semesters (Table 2). This selection was made to know the intensity, magnitude, and duration of dry and moist events during those periods. For the estimation of potential evapotranspiration, several methodologies are found in the literature. Although, Penman-Monteith's method on a daily scale is strongly recommended by the Food and Agriculture Organization (FAO), where the amount and type of variables involved in its calculation are available (Allen et al. 1998). However, the simplicity of Thornthwaite's method (Thornthwaite 1948) allows it to be applied in a broader area monthly (Pántano et al. 2017).

\subsection{Trend analysis}

The non-parametric Mann-Kendall test (Mann 1945; Kendall 1955) was used to test whether significant trends were present in the agro-climatic and climatic indices, and we used Sen's slope estimator to quantify rates of change in the R Studio software. These procedures are commonly used for time series analysis.

\section{Results}

\subsection{Thermal climatic indices}

Thermal climatic indices show the trends $\left({ }^{\circ} \mathrm{C}\right.$ decade $\left.{ }^{-1}\right)$ of annual mean temperature (AMT) (Fig. 2a, 1970-2016 and Fig. 2b, 1997-2016), the mean maximum temperature of the warmest quarter of the year (MeMaxTDJF) (Fig. 2c, 1970 2016 and Fig. 2d, 1997-2016), the absolute maximum temperature of the warmest month (aMAXTJa) (Fig. 2e, 1970 2016 and Fig. 2f, 1997-2016), and the annual thermal 


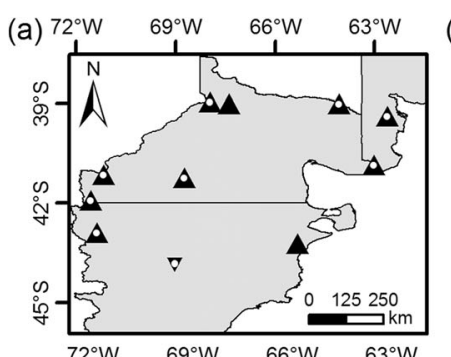

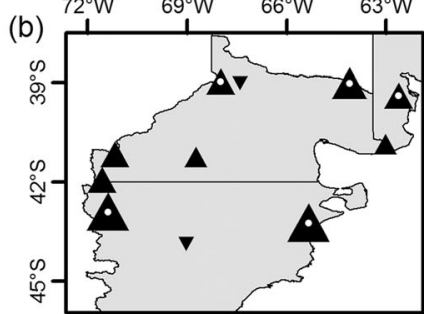

AMT $\left({ }^{\circ} \mathrm{C}\right) \quad \mathbf{\Delta} 0.4-0.8$

จ $-0.2-0 \triangle 0.8-1.2$

$\Delta 0-0.4 \Delta 1.2-1.6$
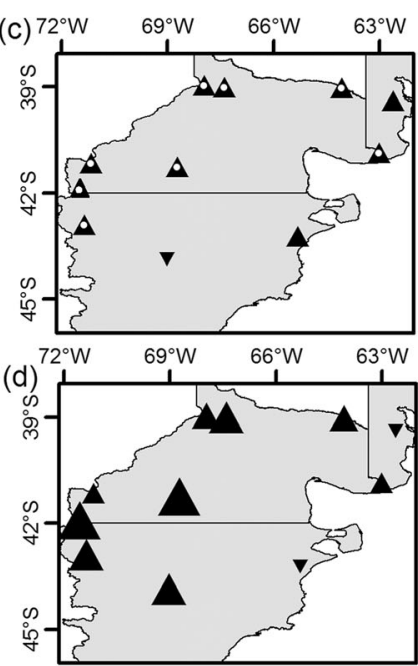

MeMaxTDJF ( $\left.{ }^{\circ} \mathrm{C}\right)$

$\checkmark-0.2-0$

$0.5-1$

$\Delta 0-0.5$

A $1-1.5$

1.5-2

Fig. 2 Spatial distribution of the trend $\left({ }^{\circ} \mathrm{C}\right.$ decade $\left.^{-1}\right)$ of annual mean temperature (AMT) (a and b), mean maximum temperature in the warmest quarter (MeMaxTDJF) (c and d), absolute maximum temperature of the warmest month (January) (aMAXTJa) (e and $\mathbf{f}$ ) and annual thermal amplitude (ATA) (g and $\mathbf{h}$ ). The top panels correspond to

amplitude (ATA) (Fig. 2g, 1970-2016 and Fig. 2h, 19972016) for the study area. Thus, the AMT was positive in ten of the 11 stations studied $(91 \%)$ in which the increase was statistically significant in nine of them $(82 \%)$ during the period 1970-2016 (Fig. 2a). For these stations, the average thermal increase was $+0.17^{\circ} \mathrm{C}$ decade $^{-1}$. During the last 20 years, the trend was also positive in $82 \%$ of the study area, but there were increments of about $0.5^{\circ} \mathrm{C}$ decade $^{-1}$ with a greater magnitude in the west region (Esquel, Bariloche, and El Bolsón, + $0.9^{\circ} \mathrm{C}$ decade $^{-1}$ ) (Fig. 2b).

On the other hand, the MeMaxTDJF showed a positive trend in $91 \%$ of the study area during the series 1970-2016 (Fig. 2c) and $82 \%$ in the shorter period (Fig. 2d). This index was statistically significant in eight of the stations analyzed (73\%) during $1970-2016\left(+0.3{ }^{\circ} \mathrm{C}\right.$ decade $\left.^{-1}\right)$, and during the subseries 1997-2016, it showed an increased (but not significant) trend of $+0.8^{\circ} \mathrm{C}$ decade $^{-1}$ (Fig. $2 \mathrm{~d}$ ).

North Patagonia showed a clearly increasing pattern in aMAXTJa and ATA in both periods analyzed. As regards aMAXTJa, the 11 stations assessed showed an incremental trend of this parameter, even though significant changes were only recorded in six stations (55\% of the study area) during the most extended period (Fig. 2e), whereas this happened in seven stations (64\%) in the series 1997-2016. Regionally, the average aMAXTJa increase during 1970-2016 was of + $0.4^{\circ} \mathrm{C}$ decade ${ }^{-1}$ increasing up to $+0.7^{\circ} \mathrm{C} \mathrm{decade}^{-1}$ in the west of the study area (Esquel, Bariloche, and El Bolsón) (Fig. 2e). During the subseries, the aMAXTJa variation was intensified,
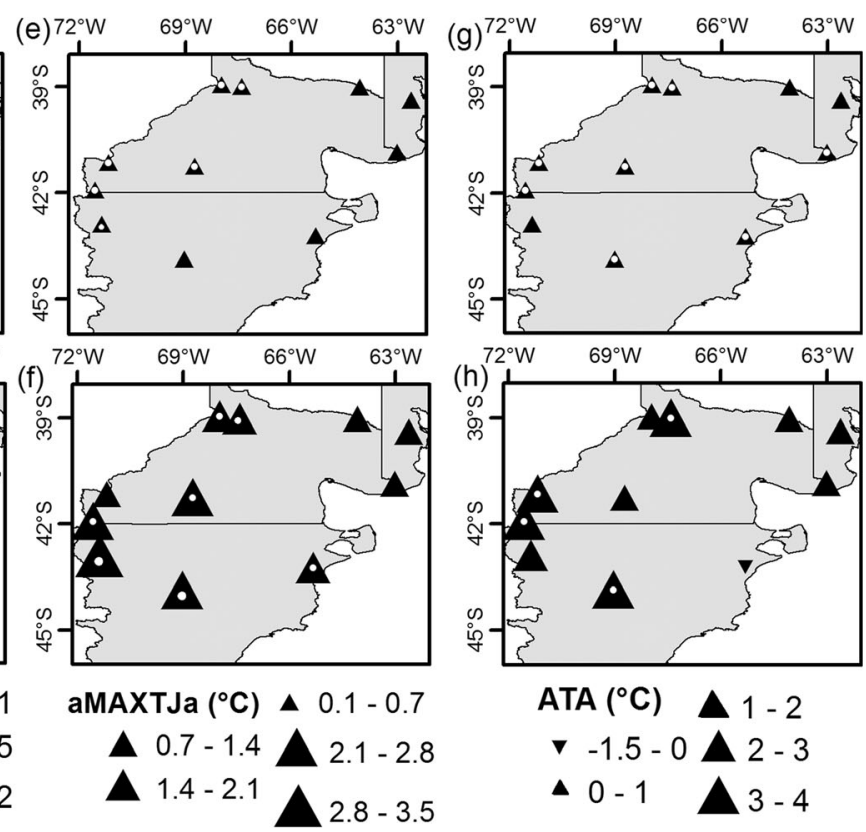

1970-2016 and those below to 1997-2016. Upward/downward pointing triangles show increasing/decreasing trends every 10 years, respectively, and points within the triangles correspond to statistically significant trends (significant at the 0.05 level)

and an average regional increase of $+1.8{ }^{\circ} \mathrm{C}$ decade $^{-1}$ was recorded (Fig. 2f).

The ATA trend was positive in the whole region during the most extended series (Fig. 2g), and it was statistically significant in eight of the stations (75\% of the study area) with an average of $+0.8^{\circ} \mathrm{C}$ decade $^{-1}$. During the shorter period, $91 \%$ of the region recorded a positive and significant trend in four localities (36\%) (Fig. 2h).

The trends $\left({ }^{\circ} \mathrm{C}\right.$ decade $\left.{ }^{-1}\right)$ of thermal climatic indices calculated from the minimum temperatures are shown in Fig. 3. The mean minimum temperature of the coldest quarter of the year (MeMinTJJA) for the period 1970-2016 (Fig. 3a) showed a positive trend in seven localities (64\%) with statistical significance in five of them $(45 \%)$. Regionally, the average increase was of $+0.1{ }^{\circ} \mathrm{C}$ decade ${ }^{-1}$. During the subseries (Fig. 3b), a change in trend was observed concerning the most extended series. It was negative in $64 \%$ of the study area with an average decrease of $-0.1{ }^{\circ} \mathrm{C}$ decade ${ }^{-1}$, and it continued being more critical, as in the series 1970-2016, in the center of the region $\left(-0.8^{\circ} \mathrm{C}\right.$ decade $\left.^{-1}\right)$.

As regards the absolute minimum temperature of the coldest month (aMINTJl) in the series 1970-2016 (Fig. 3c), $55 \%$ of the area recorded a negative trend (not significant), and $45 \%$ of the region marked a positive trend (one significant station) and an average regional trend of $-0.2{ }^{\circ} \mathrm{C}$ decade $^{-1}$. The trend in this index was maintained and intensified since it was reported in $75 \%$ of the study area with a variation of $0.9^{\circ} \mathrm{C}$ decade $^{-1}$ during the last 20 years (Fig. 3 d). 

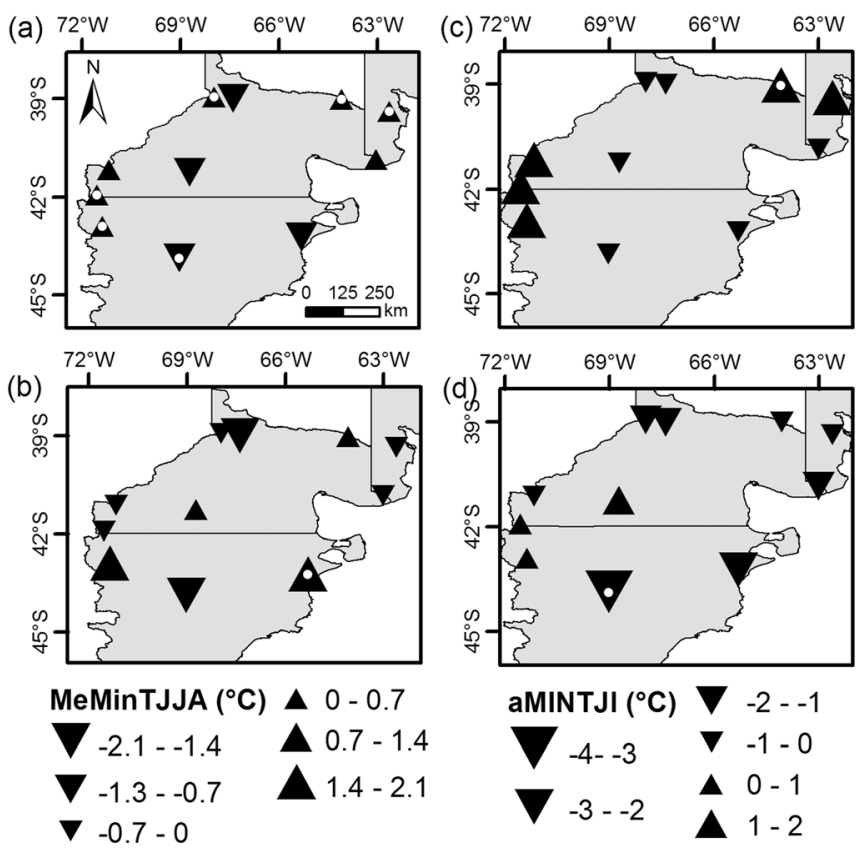

Fig. 3 Spatial distribution of the trend $\left({ }^{\circ} \mathrm{C}\right.$ decade $\left.{ }^{-1}\right)$ of the mean minimum temperature in the coldest quarter (MeMinTJJA) (a and b), absolute minimum temperature of the coldest month (July) (aMINTJl) (c and $\mathbf{d}$ ), absolute minimum temperatures of April (aMINTAp) (e and f), and the absolute minimum temperatures of October (aMINTO) (g and

Finally, the absolute minimum temperature of April (aMINTAp) (Fig. 3e, 1970-2017 and 3F 1997-2016) and the absolute minimum temperature of October (aMINTO) (Fig. 3g, 1970-2016 and Fig. 3h, 1997-2016) also showed a change in trend during the shorter series. The negative trend was observed in $73 \%$ of the study area in the first case, whereas it was $64 \%$ for the second index (Fig. $3 \mathrm{f}$ and h). The average decrease for aMINTAp was $-0.3{ }^{\circ} \mathrm{C}$ decade $^{-1}$, whereas for aMINTO, it was $-0.2^{\circ} \mathrm{C}$ decade $^{-1}$ (Fig. $3 \mathrm{f}$ and $\mathrm{h}$ ).

\subsection{Thermal agro-climatic indices}

Figure 4 shows the trends of thermal agro-climatic indices of thermal sums on a base of $5{ }^{\circ} \mathrm{C}\left(\Sigma \mathrm{T} 5{ }^{\circ} \mathrm{C}\right)$ and $10{ }^{\circ} \mathrm{C}(\Sigma \mathrm{T} 10$ $\left.{ }^{\circ} \mathrm{C}\right)\left({ }^{\circ} \mathrm{C}\right.$ decade $^{-1}$ ) (Fig. 4a, 1970-2016 and Fig. 4b, 19972016 for the first index and Fig. 4c, 1970-2016 and Fig. 4d, 1997-2016 for the second one) and the chill hours based on Weinberger's method (CHW) (h decade ${ }^{-1}$ (Fig. 4e, 19702016 and Fig. 4f, 1997-2016) and Sharpe's method (CHS) (h decade ${ }^{-1}$ )(Fig. 4g, 1970-2016 and Fig. 4h, 1997-2016).

Thus, in $\sum \mathrm{T} 5{ }^{\circ} \mathrm{C}$ and $\sum \mathrm{T} 10{ }^{\circ} \mathrm{C}$ indices, $91 \%$ (81\% statistically significant) of the study area showed a positive trend during the period 1970-2016. The average increase was of $+38.8\left(\sum \mathrm{T} 5{ }^{\circ} \mathrm{C}\right)$ and $+32.3\left(\sum \mathrm{T} 10{ }^{\circ} \mathrm{C}\right)$ Growing Degree Days (GDD) decade ${ }^{-1}$. This trend also predominated during the shorter series with an average regional increase of +136.4 $\left(\sum \mathrm{T} 5{ }^{\circ} \mathrm{C}\right)$ and $+118.3\left(\sum \mathrm{T} 10^{\circ} \mathrm{C}\right)$ GDD decade ${ }^{-1}$ during the
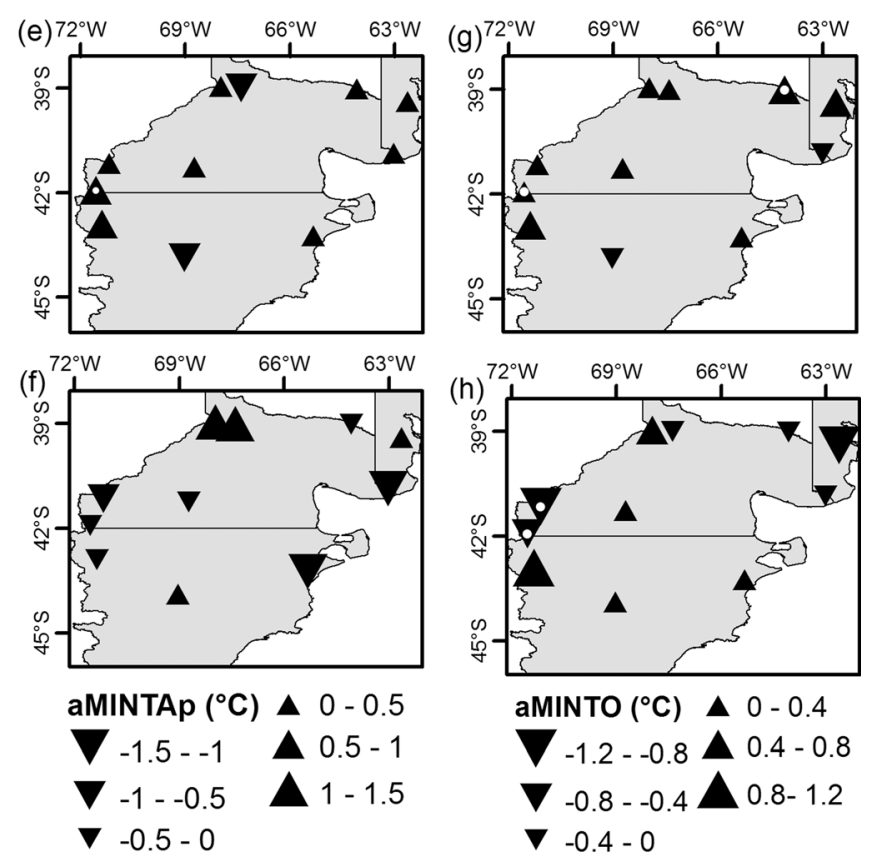

h). The top panels correspond to the 1970-2016 and those below to 1997-2016. Upward/downward pointing triangles show increasing/ decreasing trends every 10 years, respectively, and the points within the triangles correspond to statistically significant trends (significant at the 0.05 level)

period 1997-2016. The above shows a generalized rise in regional energy availability during the last decades (Fig. 4).

Regarding the CHW and CHS indices, the 1970-2016 series showed negative trends in $91 \%$ and $82 \%$ of the region, with average regional decreases of -20.8 chill hours $(\mathrm{CH})$ and $-15.8 \mathrm{CH}$ decade ${ }^{-1}$, respectively. These indices maintained negative trends during the shortest period in most of the region, decreasing by -39.1 CHW and -101.3 CHS decade $^{-1}$ (Fig. 4).

Fruit trees require a winter chill to overcome their endodormancy period and need heat in spring to leaf out and bloom for subsequent development periods. Thermal sums are measured in Growing Degree Days (GDD) that express thermal sums and Weinberger's and Sharpe's method in chill hours $(\mathrm{CH})$. Mean values \pm SE (1970-2016) of these agroclimatic thermal indices are shown in Table 3 . This allows us to have a reference for the mean values of these metrics and their geographical variability in the studied region.

\subsection{Water climatic indices}

Figure 5 represents the annual precipitation trend (mm decade $^{-1}$ ) (Fig. 5a, 1970-2016 and Fig. 5b, 1997-2016), mean precipitation the warmest semester (October-March) (Fig. 5c, 1970-2016 and Fig. 5d, 1997-2016) and the coldest semester (April-September) (Fig. 5e, 1970-2016 and Fig. 5f, 19972016) in the study area. Considering the annual precipitation during the period 1970-2016 (Fig. 5a), the region showed a 

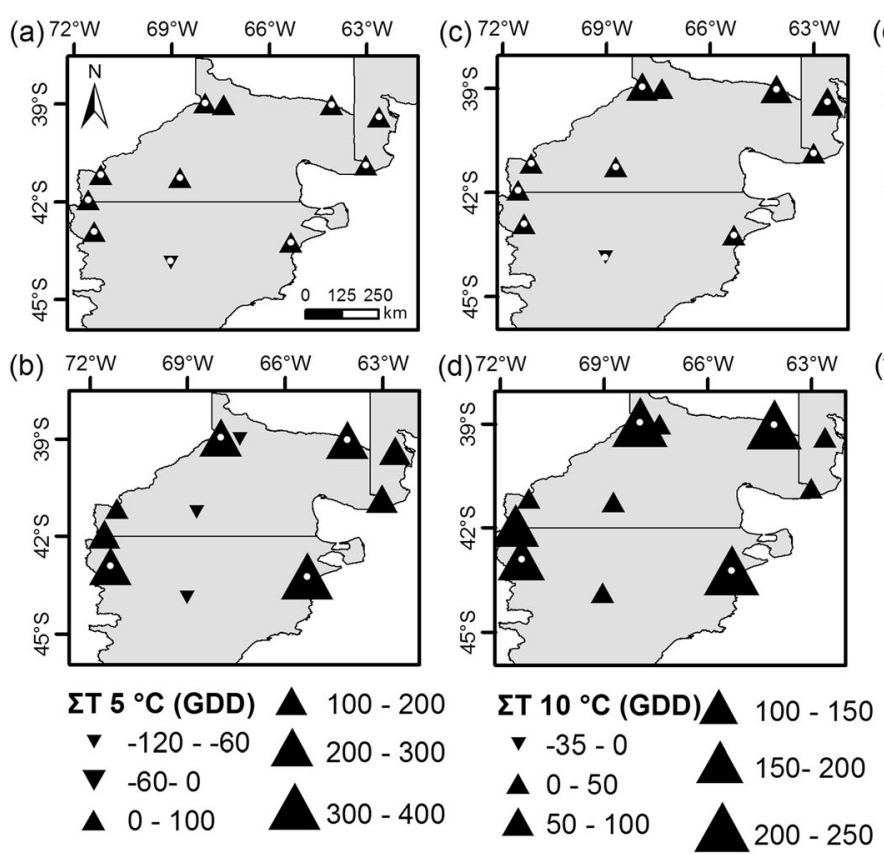

Fig. 4 Spatial distribution of the trend $\left({ }^{\circ} \mathrm{C} \mathrm{decade}{ }^{-1}\right)$ of thermal sums on a base of $5{ }^{\circ} \mathrm{C}\left(\Sigma \mathrm{T} 5^{\circ} \mathrm{C}\right)(\mathbf{a}$ and $\mathbf{b})$, thermal sums on a base of $10^{\circ} \mathrm{C}(\Sigma \mathrm{T}$ $\left.10{ }^{\circ} \mathrm{C}\right)(\mathbf{c}$ and $\mathbf{d})$, chill hours based on Weinberger's method (CHW) (h decade $\left.^{-1}\right)$ (e and f) and Sharpe's method (CHS) (h decade ${ }^{-1}$ ) (f and g).

decrease in nine localities (82\%), out of which three were statistically significant. This average decrease was of $12.5 \mathrm{~mm}$ decade $^{-1}$. The most critical variation was recorded in the west $\left(-31.2 \mathrm{~mm} \mathrm{decade}^{-1}\right.$ ) (El Bolsón, Bariloche, and Esquel). During the shortest period, the trend in this index increased since the precipitation decreased over the whole study area $\left(-51.2 \mathrm{~mm} \mathrm{decade}^{-1}\right)$ (Fig. 5b). The annual rainfall decrease was higher in the west of the region during the period 1997-2016 (-67.7 mm decade $\left.{ }^{-1}\right)$ just as happened in the $1970-2016$ series.

The trend in accumulated precipitation during the warm and cold semesters also decreased in both periods studied. As the precipitation of the warm semester (October-March) was considered during the period 1970-2016, nine localities (82\%) showed this sign in the trend, being statistically significant in $27 \%$ of the study area (Fig. $5 \mathrm{c}$ ). The average regional decrease was of $-4.1 \mathrm{~mm}$ decade $^{-1}$. During 1997-2016, ten localities presented a negative trend (Fig. $5 \mathrm{~d}$ ). In this case, the precipitation variation of the warm semester was of $-8.2 \mathrm{~mm}$ decade $^{-1}$ during the sub-period.

Finally, the precipitation accumulated in the cold semester (April-September) also showed a negative trend in nine localities (82\%), two of which were significant during the series 19702016 (Fig. 5e). This index reduction, during the last period mentioned, was of $-13.2 \mathrm{~mm} \mathrm{decade}^{-1}$. On the contrary, during the period 1997-2016, the whole study area experienced a reduction in this index, in the cold semester but without any statistical significance (Fig. 5f). This index of regional decrease for the shortest series was of $-31.9 \mathrm{~mm}$ decade $^{-1}$.
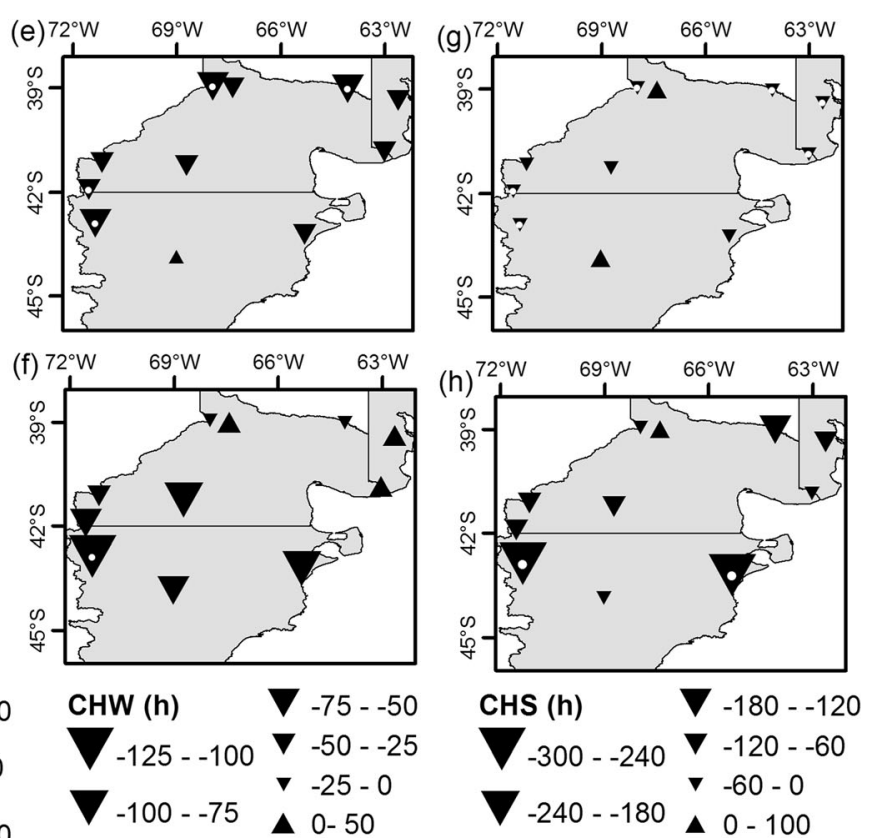

The top panels correspond to 1970-2016 and those below to 1997-2016. Upward/downward pointing triangles show increasing/decreasing trends every 10 years, respectively, and points within the triangles correspond to statistically significant trends (significant at the 0.05 level)

\subsection{Water agro-climatic indices}

Figure 6 shows the precipitation minus potential evapotranspiration trend ( $\mathrm{mm} \mathrm{decade} \mathrm{e}^{-1}$ ) on an annual scale (annual PPPET) (Fig. 6a, 1970-2016 and Fig. 6b, 1997-2016) and on a six-monthly scale during the warm semester (warm PP-PET) (Fig. 6c, 1970-2016 and Fig. 6d, 1997-2016) and the cold one (cold PP-PET) (Fig. 6e 1970-2016 and Fig. 6f, 19972016) in the study area. Considering annual PP-PET, for the complete series, ten localities $(91 \%)$ presented a negative trend, being statistically significant in six of them (Fig. 6a). This sign in the trend also predominated during the shortest series (Fig. 6b). The predominance of dry conditions was also reflected in the warm PP-PET with a negative trend in nine localities in both periods (Fig. 6c and d) and in the cold one with a negative trend in nine locations during 1970-2016 (Fig. 6e) and in the total of the area during the 1997-2016 (Fig. 6f).

\section{Discussion}

The evaluation of the thermal climatic and agro-climatic indices in the North Patagonian region indicated an increment of the caloric feasibilities over the last decades. This situation was following studies at a global level (Brown et al. 2008; Buckley and Huey 2016) and a regional level (Vincent et al. 2005). Thus, the region presented an average increase in the annual mean temperature of $+0.8^{\circ} \mathrm{C}$ during 1970-2016, and of $+0.6^{\circ} \mathrm{C}$ during $1997-2016$. This fact could be associated 
Table 3 Mean values and standard deviation of agroclimatic thermal indices $(1970$ 2016). Chill hours based on Weinberger's method (CHW) and Sharpe's method (CHS). Thermal sums (GDD) on base $5{ }^{\circ} \mathrm{C}$ $\left(\sum \mathrm{T}_{\mathrm{LN} 5}\right)$ and $10^{\circ} \mathrm{C}\left(\sum \mathrm{T}_{\mathrm{LN} 10}\right)$

\begin{tabular}{lllll}
\hline Weather station & CHW & CHS & $\sum \mathrm{T}_{\mathrm{LN} 5}$ & $\sum \mathrm{T}_{\mathrm{LN} 10}$ \\
\hline Hilario Ascasubi & $1143 \pm 110.4$ & $1604 \pm 87$ & $2939 \pm 181.4$ & $1757 \pm 134.3$ \\
Neuquén & $1339 \pm 127$ & $1814 \pm 107$ & $3396 \pm 167.9$ & $1959 \pm 133.7$ \\
Alto Valle & $1301 \pm 111.4$ & $1782 \pm 95$ & $2783 \pm 138.8$ & $1694 \pm 130.2$ \\
Rio Colorado & $1118 \pm 121.5$ & $1544 \pm 108$ & $3349 \pm 222$ & $2106 \pm 167.3$ \\
Viedma & $1188 \pm 107$ & $1694 \pm 94$ & $2876 \pm 168$ & $1695 \pm 131$ \\
Bariloche & $1808 \pm 127$ & $2581 \pm 98$ & $1313 \pm 137.5$ & $593 \pm 100$ \\
Maquinchao & $1915 \pm 192.8$ & $2583 \pm 165$ & $1803 \pm 166.2$ & $950 \pm 120.6$ \\
El Bolsón & $1592 \pm 97.9$ & $2253 \pm 86$ & $1655 \pm 144.7$ & $825 \pm 109.3$ \\
Esquel & $1836 \pm 191.4$ & $2549 \pm 137$ & $1401 \pm 140$ & $612 \pm 98.5$ \\
Trelew & $1301 \pm 138$ & $1801 \pm 116$ & $2699 \pm 144.9$ & $1574 \pm 109.6$ \\
Paso de Indios & $1680 \pm 206.2$ & $2311 \pm 179$ & $1916 \pm 178.9$ & $1025 \pm 118$ \\
\hline
\end{tabular}

with the rise in summer temperatures since records of the mean maximum temperatures during the warm quarter (Fig. $2 \mathrm{c}$ and d) showed an average increase of $+1.3{ }^{\circ} \mathrm{C}$ in the 47 years of study, having become accentuated in the last two decades. The behavior of the mean minimum temperatures of the cold trimester of the year showed an uneven spatial trend, having a negative trend increment over the last 20 years (Fig. 3a and b), which also leads to a regional ATA incremental trend (Fig. 2g and h). This previous increase in the index is mainly related to the higher summer thermal availabilities. These results comply with what was previously found out for the region by Brendel et al. (2017) and partially differed from previous studies that indicate a uniform regional increase in the winter minimum temperatures over the last decades (a)

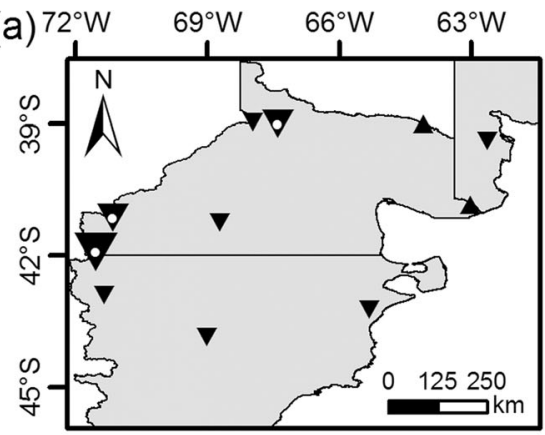

(b)

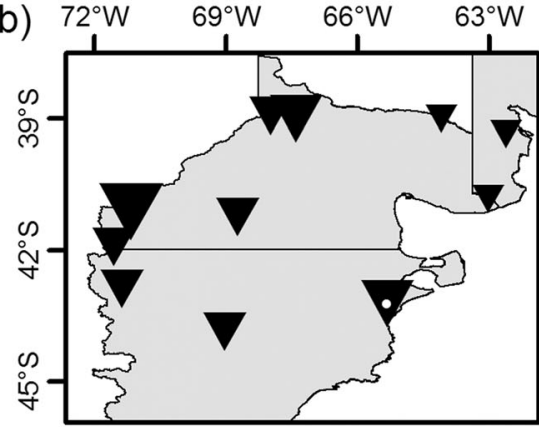

PPAnnual (mm)

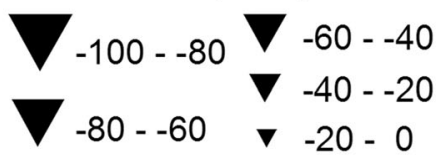

- $0-10$

Fig. 5 Spatial distribution of the trend $\left(\mathrm{mm} \mathrm{decade}^{-1}\right)$ of annual rainfall (a and $\mathbf{b}$ ), mean rainfall of the warmest semester ( $\mathbf{c}$ and $\mathbf{d}$ ), and coldest semester (e and f). Top panels correspond to the 1970-2016 and those below to 1997-2016. Upward/downward pointing triangles show
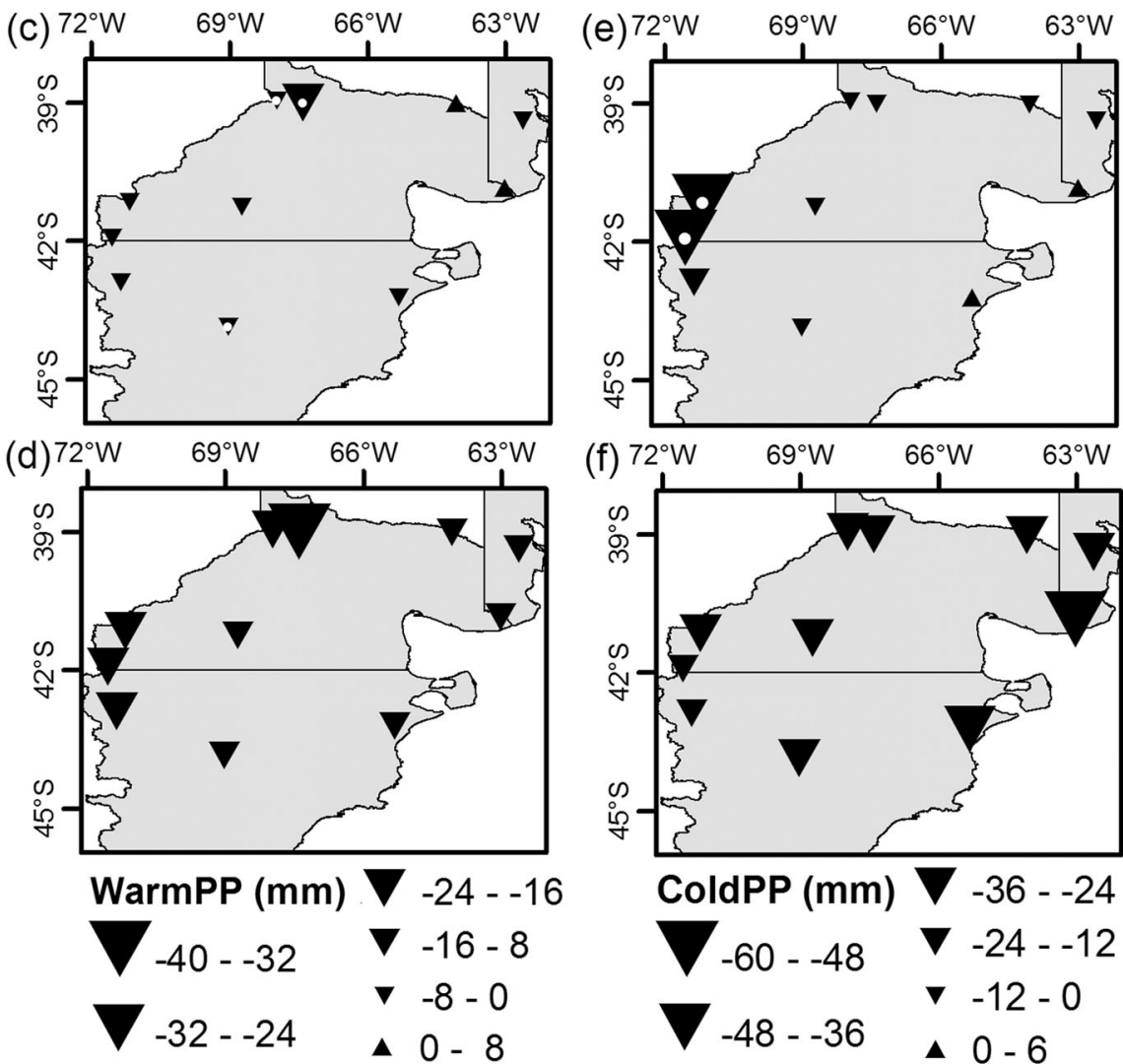

increasing/decreasing trends every 10 years, respectively, and points within the triangles correspond to statistically significant trends (significant at the 0.05 level) 

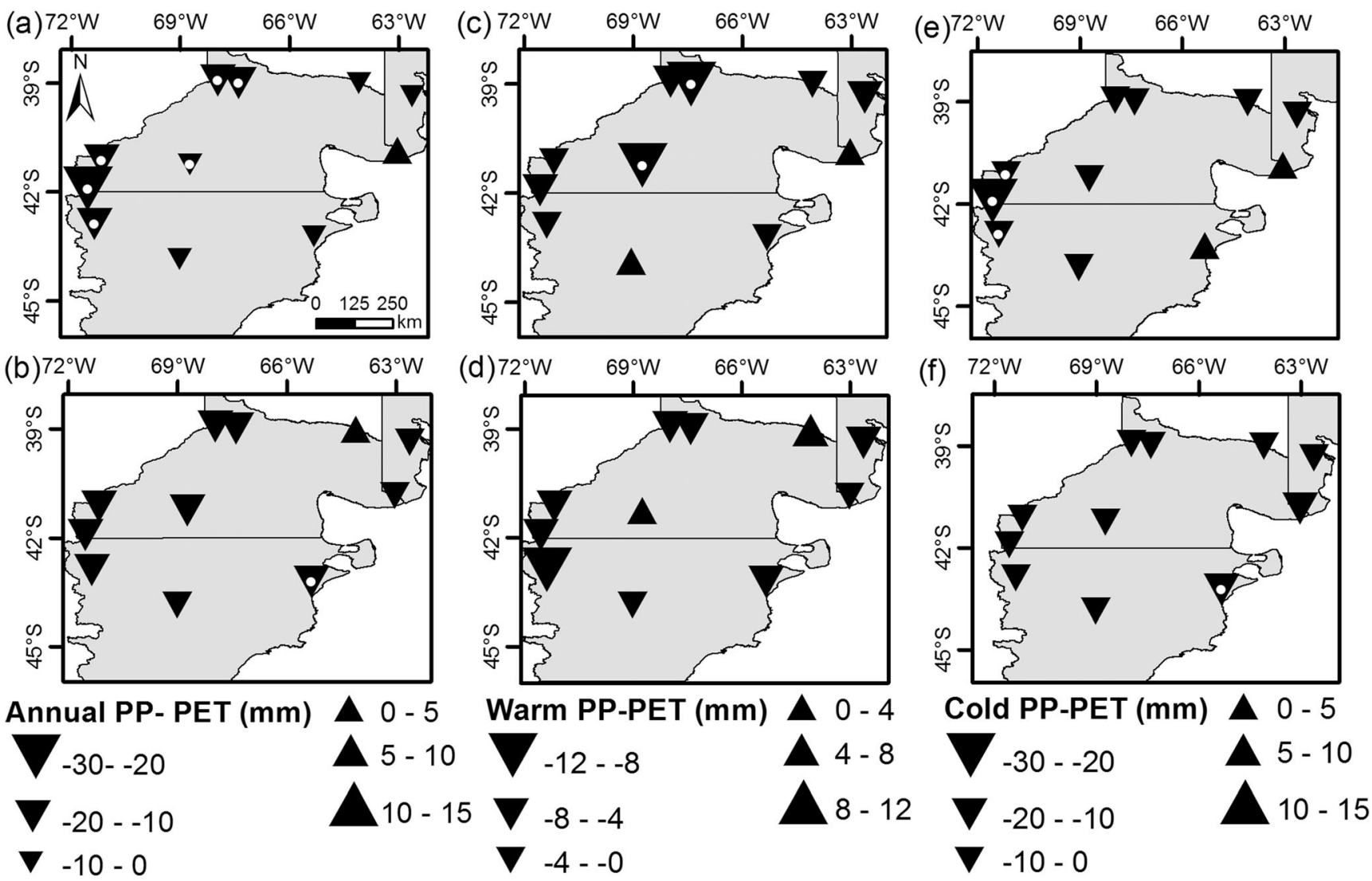

Fig. 6 Spatial distribution of trend $\left(\mathrm{mm} \mathrm{decade}^{-1}\right)$ of annual Precipitation minus the Potential Evapotranspiration (Annual PP-PET) (a and b), PPPET in the warm semester (Warm PP-PET) (c and d), and PP-PET during the cold semester (Cold PP-PET) (e and f). Top panels correspond to the

(Puga et al. 2008) or significant increments of the summer mean maximum temperatures only in the Patagonian Andean region (Zalazar and Serio 2012).

Considering the thermal extremes, the increments found in the aMAXTJa in both study periods (Fig. 2e and f) increase the risk of fruit sunburn and burn, particularly in the north of the region under analysis (Benegas and Rodríguez 2007), and modification in the organoleptic features of the vine (Sepúlveda et al. 1986). As regards the aMINTJl, the increase in the negative trends over the last 20 years (Fig. 3d) has already been causing losses of young olive plants (Martín and Gallo 2007) and walnut trees (del Barrio and Martín 2011) in the region due to winter frost injuries (Charrier et al. 2015). The abovementioned, together with the negative trends found in the aMINTAp (Fig. 3f) and aMINTO (Fig. $3 \mathrm{~h}$ ), imply more significant risks of damage due to thermal decrease during crucial phenological periods of the plants (Charrier et al. 2011).

The higher thermal availability of the warm semester is also supported by the observed results of the agro-climatic indices of thermal sums on a $5{ }^{\circ} \mathrm{C}$ base $\left(\Sigma \mathrm{T} 5{ }^{\circ} \mathrm{C}\right)($ Fig. $4 \mathrm{a}$ and b) and a $10^{\circ} \mathrm{C}$ base $\left(\Sigma \mathrm{T} 10^{\circ} \mathrm{C}\right)$ (Fig. $4 \mathrm{c}$ and d). The heat availability in spring and summer for the effective completion of the

1970-2016 and those below to 1997-2016. Upward/downward pointing triangles show increasing/decreasing trends every 10 years, respectively, and points within the triangles correspond to statistically significant trends (significant at the 0.05 level)

ontogenic cycle varies significantly according to the species and the variety or cultivar. For example, from sprouting to physiologic maturity, on a $\Sigma \mathrm{T} 10^{\circ} \mathrm{C}, 1300$ to 1700 Growing Degree Days (GDD) must be reached in walnut trees (Villaseca 2007), 700 to 1500 GDD in apple trees (Pascale et al. 2003), 500 to 1200 GDD in vines (del Barrio et al. 2016), or 500 to G700 GDD in cherry trees (Luedeling et al. 2013). Considering our database set (Table 3 ) and the results obtained in this research, these thermal requirements are met in the localities close to the Atlantic coast and those located in the North. Still, they are not enough to satisfy the crop needs (except for cherry trees) in the Andean localities (west) and those located in the center-south region. However, in the Patagonian Andean zone, the trends observed over the last two decades make it feasible, having an increased rate of an average 150 GDD every 10 years, and if the same trends continue, there is a possibility of meeting those energetic needs in the near future.

The air temperature and the development processes of the regional perennial crops, such as the deciduous fruit trees previously mentioned, are also linked using the winter chill requirements. The chill hours $(\mathrm{CH})$ for the correct induction, maintenance, and later breaking of dormancy and sprouting 
are significantly varying according to the species and variety or cultivar considered. Thus, for example, the cherry tree requires from 800 to $1300 \mathrm{CH}$ (Alburquerque et al. 2008; Luedeling et al. 2013); the walnut tree, from 500 to $1500 \mathrm{CH}$ (Vahdati et al. 2012); the hazelnut, from 700 to $1200 \mathrm{CH}$ (del Barrio and Martín 2011); and the vine, from 400 to $1200 \mathrm{CH}$ (del Barrio et al. 2016). According to the applied methodology, the study area has lost between 5.5 and $12 \%$ of its average winter chill availability over the last 47 years (Fig. $4 \mathrm{e}$ and g). Considering the previous two decades, the $\mathrm{CH}$ average decrease has become accentuated, reaching a regional average of -39 CHW decade ${ }^{-1}$ and -101 CHS decade ${ }^{-1}$ by Weinberger and Sharpe, respectively (Fig. $4 \mathrm{f}$ and $\mathrm{h}$ ). In the future, this decrease in the winter chill could be a limitation for high-chill cultivars cultivated in the warmer regions of North Patagonia. However, it should be highlighted that projections of winter chill that use the Chilling Hour Model have projected substantial declines in future winter chill in warm regions (Baldocchi and Wong 2008; Luedeling et al. 2009b, 2011), whereas changes indicated by the Dynamic Model tend to be less severe (Luedeling et al. 2009c,d). Still, historical winter chill changes between the Chilling Hour Model and the Dynamic Model were not very high in cold Germany (Luedeling et al. 2009e) with similar conditions as cold Patagonia, which supports the validity of Chilling Hour Model as a first approach.

The water climatic indices did not present a similar spatial trend during the period 1970-2016. Thus, the annual precipitation increased in some locations of the coastal zone (Fig. 5a). In contrast, it decreased in the south-center of the region and over the Andes (average of $-54 \mathrm{~mm}$ and $-147 \mathrm{~mm}$, respectively, over the 47 years assessed). These decreasing rates were higher in the last 20 years than those obtained during 1970-2016 (Fig. 5b). During the last two decades, in the coastal zone, the precipitation decreased $-24 \mathrm{~mm}$ and $54 \mathrm{~mm} \mathrm{decade}{ }^{-1}$ in the south-center. The principal reduction was found in the Andean area showing $-67 \mathrm{~mm}$ decade $^{-1}$, mainly due to the decrease recorded in the precipitation that took place during the cold semester (Fig. 5e and f). If this negative regional trend is maintained in the future, it will lead to erosion and desertification processes. Moreover, the lower water availability in the western Andean area would affect the recharge of the upper watersheds of the principal regional rivers and, consequently, the intensive agriculture under irrigation further downstream (Rivera et al. 2017). The water availability analysis conducted from annual and semesterly PP-PET indices also presented a negative trend in most of the localities studied during the period 1970-2016 (Fig. 6a). The use of PP-PET at different scales and periods of the year allowed a more accurate assessment of the water situations relating to gains and losses of soil water (Bohn and Piccolo 2019). Most of the negative values found in these indices are directly related to the combination of lower precipitation and higher energetic availability for potential evapotranspiration.

\section{Conclusion}

The current agricultural aptitude of north Argentine Patagonia presents availabilities and restrictions expressed by temporal and spatial changes in their thermal and hydric conditions, as found over the last five decades. Thus, the positive trend observed in the thermal indices, if maintained in the future, will evolve into a greater energetic availability that will improve the possibilities of crop growth and development in the region studied. However, there could be two restrictions related to this increase: on the one hand, the smaller availability of winter chill needed for the development of very high-chill cultivars or species, specifically in the north and northeast of the region and, on the other hand, the higher intensity of extreme thermal events. The latter may be expressed in the trends of the absolute temperature of the warmest and coldest months as well as the absolute minimum temperatures in autumn and spring (risk of early and late frosts) with consequences in crop phenology and yield.

In addition, the decreasing water availabilities will have a more significant impact on the dry farming in the plateaus of the coastal and center-south zones of the area studied, where the decline associated with the degradation of natural grassland will be maintained. Moreover, if these trends are maintained, the water availability for agricultural irrigation in the valleys of the river basins with less abundant water, e.g., the Colorado and Chubut rivers, could be affected in the future.

Funding information The authors received support from Universidad Nacional de Rio Negro (Grant No. PI 40-C-356).

\section{References}

Adnan S, Ullah K, Gao S, Khosa A, Wang Z (2017) Shifting of agroclimatic zones, their drought vulnerability, and precipitation and temperature trends in Pakistan. Int J Climatol 37(S1):529-543. https://doi.org/10.1002/joc.5019

Alburquerque N, García-Montiel F, Carrillo A, Burgos L (2008) Chilling and heat requirements of sweet cherry cultivars and the relationship between altitude and the probability of satisfying the chill requirements. Environ Exp Bot 64(2):162-170. https://doi.org/10.1016/j. envexpbot.2008.01.003

Alessandro AP (2008) Temperature and precipitation conditions in Argentina associated with strong westerly mid-latitute. Rev Bras Meteorol 23:126-142. https://doi.org/10.1590/S010277862008000200002

Alessandro AP (2012) Relationship between values and trends of two circulation indices and temperature and rainfall in Argentina. Meteorol Appl 19(4):427-442. https://doi.org/10.1002/met.274

Alexander LV, Zhang X, Peterson TC, Caesar J, Gleason B, Klein Tank AMG, Haylock M, Collins D, Trewin B, Rahimzadeh F, Tagipour A, Rupa Kumar K, Revadekar J, Griffiths G, Vincent L, Stephenson DB, Burn J, Aguilar E, Brunet M, Taylor M, New M, Zhai P, Rusticucci M, Vazquez-Aguirre JL (2006) Global observed changes in daily climate extremes of temperature and precipitation. $\mathrm{J}$ Geophys Res-Atmos 111(5):1-22. https://doi.org/10.1029/ 2005JD006290 
Allen RG, Pereira LS, Raes D, Smith M (1998) Crop evapotranspiration: guidelines for computing crop requirements. Irr drain paper 56. UNFAO, Rome

Aravena JC, Luckman BH (2009) Spatio-temporal rainfall patterns in southern South America. Int J Climatol 29(14):2106-2120. https:// doi.org/10.1002/joc. 1761

Argentine Board of Integrated Fruit Growers (2018) Cámara Argentina de Fruticultores Integrados, CAFI (2018) Producción Argentina de peras y manzanas 1-4. http://www.cafi.org.ar/nuestra-producción/ (In Spanish). Accessed 1 March 2019

Baldocchi D, Wong S (2008) Accumulated winter chill is decreasing in the fruit growing regions of California. J Clim Change 87(1):153166. https://doi.org/10.1007/s10584-007-9367-8

Barrett BS, Garreaud R, Falvey M (2009) Effect of the Andes Cordillera on precipitation from a mid-latitude cold front. Mon Weather Rev 137(9):3092-3109. https://doi.org/10.1175/2009MWR2881

del Barrio RA, Martín DM (2011) A the agro-climatic aptitude of the lower Negro River valley for hazelnut and walnut crops. PilquenSección Agronomía 1-10(In Spanish):11

del Barrio RA, Gallo SL, Martín DM (2016) Bio and agro-climatic aspects of grapevine to vinify in the lower Negro River valley. Revista de Investigaciones Agropecuarias 42(3):283-290 (In Spanish)

del Barrio RA, Fernandez E, Brendel AS, Whitney C, Campoy JA, Luedeling E (2020) Climate change impacts on agriculture's southern frontier - perspectives for farming in North Patagonia. Int J Climatol. https://doi.org/10.1002/joc.6649

Benegas R, Rodríguez A (2007) Factors that affect the percentage of sunny fruit in apple CV tree in the upper valley of the Negro River and Neuquén. Revista de Investigaciones Agropecuarias 36(1):131146 (In Spanish)

Benmoussa H, Luedeling E, Ghrab M, Yahmed JB, Mimoun MB (2017) Performance of pistachio (Pistacia vera L.) in warming Mediterranean orchards. Environ Exp Bot 140:76-85. https://doi. org/10.1016/j.envexpbot.2017.05.007

Bianchi E, Villalba R, Viale M, Couvreux F, Marticorena R (2016) New precipitation and temperature grids for northern Patagonia: advances in relation to global climate grids. J Meteorol Res 30(1):38-52. https://doi.org/10.1007/s13351-015-5058-y

Bohn VY, Piccolo MC (2019) Estimation of hydrological vulnerability in river basins of Argentinean plains. Int J River Basin Manag:1-13. https://doi.org/10.1080/15715124.2019.1683855

Brendel AS, Mora F, del Barrio RA (2017) The Patagonian region's current and potential agro-climatic aptitude for the cultivation of walnut (Juglans regia L.) in a context of climate change. Revista Argentina de Agrometerología 5:15-27 (In Spanish)

Brown SJ, Caesar J, Ferro CA (2008) Global changes in extreme daily temperature since 1950. J Geophys Res-Atmos 113(5):1-11. https:// doi.org/10.1029/2006JD008091

Buckley LB, Huey RB (2016) Temperature extremes: geographic patterns, recent changes, and implications for organismal vulnerabilities. Glob Chang Biol 22(12):3829-3842. https://doi.org/10.1111/ gcb. 13313.7

Campoy JA, Ruiz D, Egea J (2011) Dormancy in temperate fruit trees in a global warming context: a review. Sci Hortic 130(2):357-372. https://doi.org/10.1016/j.scienta.2011.07.011

Charrier G, Bonhomme M, Lacointe A, Améglio T (2011) Are budburst dates, dormancy and cold acclimation in walnut trees (Juglans regia L.) under mainly genotypic or environmental control? Int $\mathrm{J}$ Biometeorol 55(6):763-774. https://doi.org/10.1007/s00484-0110470-1

Charrier G, Ngao J, Saudreau M, Ameglio T (2015) Effects of environmental factors and management practices on microclimate, winter physiology, and frost resistance in trees. Front Plant Sci 6(259). https://doi.org/10.3389/fpls.2015.00259

Chen A, He X, Guan H, Cai Y (2017) Trends and periodicity of daily temperature and precipitation extremes during 1960-2013 in Hunan
Province, central south China. Theor Appl Climatol 132:71-88. https://doi.org/10.1007/s00704-017-2069-x

Cittadini ED, Sanz CE, Pugh AB, Peri PL, Szlápelis E, Cárcamo MA, Kikuchi N, Manavella F, San Martino L, Ñancucheo JA, Muñoz M, de Ridder N, van Keulen H, Mundet CA (2008) Sweet cherry production in south Patagonia Argentina. Acta Hortic (795):585-590. https://doi.org/10.17660/ActaHortic.2008.795.92

Doyle ME, Saurral RI, Barros VR (2012) Trends in the distributions of aggregated monthly precipitation over the La Plata Basin. Int J Climatol 32(14):2149-2162. https://doi.org/10.1002/joc.2429

Duchêne E, Huard F, Dumas V, Schneider C, Merdinoglu D (2010) The challenge of adapting grapevine varieties to climate change. Clim Res 41(3):193-204. https://doi.org/10.3354/cr00850

Fernández-Long ME, Müller GV, Beltrán-Przekurat A, Scarpati OE (2013) Long-term and recent changes in temperature-based agroclimatic indices in Argentina. Int J Climatol 33(7):1673-1686. https://doi.org/10.1002/joc.3541

Galán C, García-Mozo H, Vázquez L, Ruiz L, De La Guardia CD, Trigo MM (2005) Heat requirement for the onset of the Olea europaea L. pollen season in several sites in Andalusia and the effect of the expected future climate change. Int J Biometeorol 49(3):184-188. https://doi.org/10.1007/s00484-004-0223-5

Garcia Martinez GC, Ciari G, Gaitan JJ, Opazo WJ, Caruso CA, Nagahama N, Nakamatsu VB, Lloyd CE, Antiman Cotut CR, Escobar JM (2017) Diagnosis of the evolution of the climate, natural grasslands and livestock loads in the northwest of Chubut province during 2000-2014. AgriScientia 34:59-69 (In Spanish)

Garcia RA, Cabeza M, Rahbek C, Araújo MB (2014) Multiple dimensions of climate change and their implications for biodiversity. Science 344:486-496. https://doi.org/10.1126/science.1247579

González MH, Vera CS (2010) On the interannual wintertime rainfall variability in the southern Andes. Int J Climatol 30(5):643-657. https://doi.org/10.1002/joc.1910

IPCC (2013) In: Stocker TF, Qin D, Plattner GK, Tignor M, Allen SK, Boschung J, Nauels A, Xia Y, Bex V, Midgley PM (eds) Climate change 2013: the physical science basis. Contribution of Working Group I Contribution to the Fifth Assessment Report of the Intergovernmental Panel on Climate Change. Available from Cambridge University Press, United Kingdom and New York $1535 \mathrm{pp}$

Kendall MR (1955) Rank correlation methods, 4th edn. Chareles Griffin, London

Kottek M, Grieser J, Beck C, Rudolf B, Rubel F (2006) World map of the Köppen-Geiger climate classification updated. Meteorol Z 15(3): 259-263. https://doi.org/10.1127/0941-2948/2006/0130

Legave JM, Blanke M, Christen D, Giovannini D, Mathieu V, Oger R (2013) A comprehensive overview of the spatial and temporal variability of apple bud dormancy release and blooming phenology in Western Europe. Int J Biometeorol 57(2):317-331. https://doi.org/ 10.1007/s00484-012-0551-9

Luedeling E (2012) Climate change impacts on winter chill for temperate fruit and nut production: a review. Sci Hortic-Amsterdam 144:218 229. https://doi.org/10.1016/j.scienta.2012.07.011

Luedeling E, Brown PH (2011) A global analysis of the comparability of winter chill models for fruit and nut trees. Int J Biometeorol 55(3): 411-421. https://doi.org/10.1007/s00484-010-0352-y

Luedeling E, Zhang M, McGranahan G, Leslie C (2009a) Validation of winter chill models using historic records of walnut phenology. Agric For Meteorol 149(11):1854-1864. https://doi.org/10.1016/j. agrformet.2009.06.013

Luedeling E, Zhang M, Girvetz EH (2009b) Climatic changes lead to declining winter chill for fruit and nut trees in California during 1950-2099. PLoS One 4(7):6166. https://doi.org/10.1371/journal. pone. 0006166

Luedeling E, Gebauer J, Buerkert A (2009c) Climate change effects on winter chill for tree crops with chilling requirements on the Arabian 
Peninsula. Clim Chang 96:219-237. https://doi.org/10.1007/ s10584-009-9581-7

Luedeling E, Zhang M, Luedeling V, Girvetz EH (2009d) Sensitivity of winter chill models for fruit and nut trees to climatic changes expected in California's Central Valley. Agric Ecosyst Environ 133: 23-31. https://doi.org/10.1016/j.agee.2009.04.016

Luedeling E, Blanke M, Gebauer J (2009e) Effects of climate change on the availability of chilliness for fruit trees in Germany. ErwerbsObstbau 51(3):81-94. https://doi.org/10.1007/s10341-009-0085-4 (In German)

Luedeling E, Girvetz EH, Semenov MA, Brown PH (2011) Climate change affects winter chill for temperate fruit and nut trees. PLoS One 6(5):20155. https://doi.org/10.1371/journal.pone.0020155

Luedeling E, Kunz A, Blanke MM (2013) Identification of chilling and heat requirements of cherry trees - a statistical approach. Int $\mathrm{J}$ Biometeorol 57(5):679-689. https://doi.org/10.1007/s00484-0120594-y

Mann HB (1945) Non-parametric tests against trend. Econométrica 13: 245-259

Martín DM, Gallo S (2007) Climatic conditions for the cultivation of the olive trees. Serie Comunicaciones, Instituto Nacional de Tecnología Agropecuaria 17(54):28-29 (In Spanish)

Martínez-Fernández J, González-Zamora A, Sánchez N, Gumuzzio A (2015) A soil water based index as a suitable agricultural drought indicator. J Hydrol 522:265-273. https://doi.org/10.1016/j.jhydrol. 2014.12.051

Moonen, AC, Ercoli L, Mariotti, M, Masoni, A (2002) Climate change in Italy indicated by agrometeorological indices over 122 years. Agric For Meteorol 111(1):13-27. https://doi.org/10.1016/S01681923(02)00012-6

Nasir MJ, Khan AS, Alam S (2018) Climate change and agriculture: an overview of farmers perception and adaptations in Balambat Tehsil, District Dir Lower, Pakistan. Sarhad J Agric 34(1):85-92. https:// doi.org/10.17582/journal.sja/2018/34.1.85.92

Oñatibia GR, Aguiar MR (2016) Continuous moderate grazing management promotes biomass production in Patagonian arid rangelands. J Arid Environ 125:73-79. https://doi.org/10.1016/j.jaridenv.2015. 10.005

Pántano VC, Penalba OC, Spescha LB, Murphy GM (2017) Assessing how accumulated precipitation and long dry sequences impact the soil water storage. Int J Climatol 37:4316-4326. https://doi.org/10. 1002/joc. 5087

Parmesan C, Yohe G (2003) A globally coherent fingerprint of climate change impacts across natural systems. Nature 421:37-42. https:// doi.org/10.1038/nature01286

Pascale A, Damario JE (2004) Agricultural bioclimatology and agro-climatology. Facultad de Agronomía, Universidad Nacional de Buenos Aires, Buenos Aires, Argentina (In Spanish)

Pascale A, Damario JE, Bettler J (2003) The current agro-climatic aptitude of Cinco Saltos (Argentina) for the apple trees cultivation. In: XIII Congreso Brasileiro de Agrometeorología, Santa María, Brasil, pp 567-568 (In Spanish)

Pérez-López D, Ribas F, Moriana A, Rapoport HF, De Juan A (2008) Influence of temperature on the growth and development of olive (Olea europaea L.) trees. J Hortic Sci Biotechnol 83(2):171-176. https://doi.org/10.1080/14620316.2008.11512366

Puga Y, Salaverry E, Scarpati OE (2008) Analysis of temperatures in some locations in northwestern Patagonia. In: X Jornadas de
Investigación del Centro de Investigaciones Geográficas y del Departamento de Geografía, Argentina (In Spanish)

Qian B, De Jong R, Gameda S, Huffman T, Neilsen D, Desjardins R, McConkey B (2013) Impact of climate change scenarios on Canadian agroclimatic indices. Can J Soil Sci 93(2):243-259. https://doi.org/10.4141/cjss2012-053

Rabassa J (2010) Global climate change in Patagonia from Charles Darwin's Journey to our days. Rev Asoc Geol Argent 67:139-156 (In Spanish)

Rivera JA, Araneo DC, Penalba OC, Villalba R (2017) Regional aspects of streamflow droughts in the Andean rivers of Patagonia, Argentina. Links with large-scale climatic oscillations. Hydrol Res 49(1):134-149. https://doi.org/10.2166/nh.2017.207

Rusticucci M, Barrucand M (2004) Observed trends and changes in temperature extremes over Argentina. J Clim 17:4099-4107. https://doi. org/10.1175/1520-0442(2004)017<4099:OTACIT>2.0.CO;2

Secretariat of Environment and Sustainable Development, SAyDS (2015) Third National Communication presented to The Framework Convention of the United Nations on Climate Change, Argentina (In Spanish). https://www.argentina.gob.ar/ambiente/cambioclimatico/tercera-comunicacion Accessed 03 May 2018

Sepúlveda G, Kliewer WM, Ryugo K (1986) Effect of high temperature on grapevines (Vitis vinifera L.). Am J Enol Vitic 37(1):20-25

Sharpe RH (1970) Sub-tropical peaches and nectarines. Florida State Hortic Soc 82:302

Thornthwaite CW (1948) An approach toward a rational classification of climate. Geogr Rev 38(1):55-94. https://doi.org/10.2307/210739

Vahdati K, Aslamarz AA, Rahemi M, Hassani D, Leslie C (2012) Mechanism of seed dormancy and its relationship to bud dormancy in Persian walnut. Environ Exp Bot 75:74-82. https://doi.org/10. 1016/j.envexpbot.2011.08.006

Villaseca CS (2007) Walnut: a demanding species in soil and climate. Tierra Adentro, pp 33-35 (In Spanish)

Vincent LA, Peterson TC, Barros VR, Marino MB, Rusticucci M, Carrasco G, Ramirez E, Alves LM, Ambrizzi T, Berlato MA, Grimm M, Marengo JA, Molion L, Moncunill DF, Rebello E, Anunciação YM, Quintana J, Santos JL, Baez J, Coronel G, Garcia J, Trebejo I, Bidegain M, Haylock MR, Karoly D (2005) Observed trends in indices of daily temperature extremes in South America 1960-2000. J Clim 18:5011-5023. https://doi.org/10. 1175/JCLI3589.1

Weinberger JH (1950) Chilling requirements of peach varieties. Proc Am Soc Hortic Sci 56:8-122

Westra S, Alexander LV, Zwiers FW (2013) Global increasing trends in annual maximum daily precipitation. J Clim 26(11):3904-3918. https://doi.org/10.1175/JCLI-D-12-00502.1

World Meteorological Organization (2011) Guide to Climatological Practices, Geneva WMO-No 100

Zalazar SM, Serio LA (2012) The trend of the maximum and minimum monthly temperatures in Argentina (1950-2011). In: XIV Reunión Argentina de Agrometeorología, Malargüe, Mendoza, Argentina, pp 69-70 (In Spanish)

Publisher's note Springer Nature remains neutral with regard to jurisdictional claims in published maps and institutional affiliations. 


\section{Affiliations}

Andrea Soledad Brendel ${ }^{1,2}$ (D) Ricardo Alfredo del Barrio ${ }^{2,3} \cdot$ Francisco Mora $^{2}$ • Elmer Adolfo Orrego León ${ }^{4}$. Johaner Rosales Flores ${ }^{5}$. José Antonio Campoy ${ }^{6}$

1 Argentine Institute of Oceanography (IADO), National University of the South (UNS)-CONICET, Building E1, B8000BFW, Bahía

Blanca, Buenos Aires, Argentina

2 Department of Agronomy, National University of the South (UNS), Bahía Blanca, Buenos Aires, Argentina

3 Atlantic Venue, National University of Río Negro (UNRN),

Viedma, Río Negro, Argentina
4 Private Institute of Climate Change Research (ICC), Escuintla, Guatemala

5 National University, Campus Omar Dengo, Heredia, Costa Rica

6 Department of Plant Developmental Biology, Max Planck Institute for Plant Breeding Research, Cologne, Germany 